\title{
CHARACTERISTICS OF THE ATTRIBUTES OF THE ADMINISTRATIVE PROCEDURAL LAW PRINCIPLES
}

\author{
Sharaia A. A., Pokataiev P. S.
}

\section{INTRODUCTION}

The principles of administrative procedural law are the central categories of the administrative procedural law and belong to the fundamental concepts of this sub-branch of administrative law that is why importance is being increasingly attached to the need to define the concept of "principles of administrative procedural law" and formulate their characteristic attributes. Quite often, the principles and their significance for the formation of any branch, sub-branch and institute of law are underestimated and considered only transitive and transient doctrinal provisions. The lack of in-depth comprehensive attention among scholars of administrative law to the study of the principles of administrative procedural law creates an impression that these principles do not have a significant impact on the regulation of social relations, are secondary and supportive premises. However, it should be noted that administrative law as a whole is very rapidly developing, its subject, content, and system are being revised systematically, and the scholars of administrative law have been paying increasingly greater attention to the nature and role of administrative procedural law as a subbranch of administrative law, so the analysis of modern doctrinal approaches to defining the concept of principles as the fundamental category of the latter plays an important role. Present-day changes that are taking place in the political, social and legal life of Ukraine also require a renewed perspective on the principles of the administrative procedural law as a sub-branch of administrative law.

\section{Principles of administrative procedural law as a derivative category of principles of administrative law}

Given that administrative procedural law is a structural part of administrative law (being, in particular, its sub-branch), it should be considered that the "principles of administrative procedural law" are part of a broader and more complex concept, namely, the "principles of administrative law", the definition and basic doctrinal approaches to which should be considered in more detail. Determining the essence of the latter, the authors of the textbook "Administrative Law of Ukraine", edited by Yu.P. Bytiak, V.M. Harashchuk and V.V. Zui, noted that the principle is "the basis of law, it is an active center capable of playing a leading and guiding role in the 
formation and development of administrative law. They express its nature, ensure the unity of its scope, define its focus and the most essential features of regulation" ". It is safe to say that principles are a foundation on the basis of which scholarly research and normative processes are being carried out. V.K. Kolpakov rightly states that the principles of administrative law are "positive regularities, known in scholarship and practice, enshrined in legal norms, or a generalization of the rules in effect in the state"2. That is, the scholar emphasizes that the principles of administrative law are objective substantive connection, which is based on experience, facts, tested by both scholarship and practice, and is directly reflected in the rules of law, "governmental rules". Indeed, it should be borne in mind that the principles are primary with respect to the rules of law, because, even if they are not explicitly named or defined, they are still always taken into account when making and modifying the rules of law.

Noteworthy is the definition of the principles of administrative law given in the monograph of the same name, edited by T.O. Kolomoiets and P.O. Baranchyk, which defines them as "imperative, unconditional, universal, enshrined in the rules of administrative law provisions that outline in general terms the rules of behavior of its subjects and to which administrative and legal norms must comply"3. This definition is quite broad in its scope and includes an extended range of characteristics of administrative law principles that should also be addressed. Thus, the imperative of certain provisions is that they require unconditional subordination, response, fulfillment, and have a definite imperative modality - that is, if a separate provision is formulated as a principle, relevant scholarly research and rulemaking processes must be based on it. The unconditional character of the principles of administrative law presupposes that they should not be restricted, are complete in their scope and independent of any conditions. The universality of the principles of administrative law means that they have different purposes, can be "adapted" to different spheres or system elements, and are comprehensive. The fact that the principles are enshrined in the rules of administrative law reflects the close relationship between these interdependent elements, which is manifested in the situation where the principles of administrative law necessarily determine the rules of conduct of its subjects. Thus, it can be concluded that scholars of administrative law, offering their own approaches to defining the concept of "principles of administrative law" tend to agree on the following: 1) the principles of administrative law are the essential premises, ideas, provisions on

\footnotetext{
${ }^{1}$ Адміністративне право : підручник / [Ю.П. Битяк, В.М. Гаращук, В.В. Богуцький та ін.] ; за заг. ред. Ю. П. Битяка, В.М. Гаращука, В. В. Зуй. Харків : Право, 2010. С. 33-34.

${ }_{2}$ Колпаков В.К., Кузьменко О.В. Адміністративне право України : підруч. Київ : Юрінком Інтер, 2003. С. 18.

${ }^{3}$ Коломоєць Т.О., Баранчик П.О. Принципи адміністративного права : монографія. Запоріжжя : Поліграфичний центр «Сору Art», 2012. С. 44.
} 
which the branch is based; 2) they are the footing for the formation and functioning of the system and scope of the branch; 3) they are the foundation of the legal rules; 4) they are the basis of the activity of the subjects of administrative law; 5) they are a guarantee of ensuring the rights and freedoms of the individual and the citizen, the proper functioning of civil society and the state. It is hardly possible to argue with the validity of these theses, so it should be noted that they reflect the true scope and meaning of the principles of administrative law, and therefore should be the foundation for formulating a single, generally accepted doctrinal definition of the principles of administrative law, and subsequently the principles of administrative procedural law as sub-branch principles, and its subsequent normative consolidation. A.S. Kravtsov, reviewing the system of principles of administrative law, distinguishes the general (branch-wide), special (specific), sub-branch and private (institutional) principles of administrative $\mathrm{law}^{4}$, in connection with which it can be said that the principles of administrative procedural law occupy their own "niche" among sub-branch principles of administrative law. At the same time, it is worth supporting R.C. Melnyk, who rightly emphasizes that "the principles of administrative law and the principles of administrative procedure are not synonymous, and therefore it is necessary to see the difference between them, because the principles of administrative procedure are a specific list of administrative law principles in only one sphere of public administration, the administrative procedural one. The principles of administrative law, so to speak, cover all directions and spheres of functioning of public administration, in particular, those that find expression in its depth (internal organizational relations)", and one should refrain from equating the "principles of administrative law" with the "principles of administrative procedural law." This thesis should be considered as "basic" in the further analysis of the principles of administrative procedural law and their definition.

\section{The essence of the principles of administrative procedural law}

Thus, considering the principles of administrative procedural law as derived from the principles of administrative law (as one of the elements used in a specific area of relations - the administrative procedural one), scholarly approaches to their definition and characteristics of scope should be examined. So, in particular, O.I. Mykolenko, thoroughly analyzing the subject of the discipline of administrative procedural law, notes that at present "the subject does not completely reflect the object of the discipline, since many aspects and properties of the object are not considered essential

4 Кравцов А.С. Пріоритет прав і свобод людини та громадянина як принцип адміністративного права України: автореф. дис. ... канд. юрид. наук : 12.00.07. Київ, 2011. C. 17. 
and relevant for this period of time, while others are simply unknown ${ }^{5}$. In this connection, the scholar proposes to include in the subject of the discipline of administrative procedural law (which is the name he proposes to use) a number of elements (history of origin and development; categorical framework; methodology; subject and method; administrative procedural rules; administrative procedural relations, etc.) among which a separate position is occupied by the goals and principles of administrative procedural regulation ${ }^{6}$. Thus, attention should be paid to the fact that the principles in his definition occupy their own "niche" in the structure of administrative procedural law, along with other independent structural elements, and one cannot but agree with that. O.S. Lagoda states that "the essence of administrative procedural regulation of relations lies in the proper use of the principles that underpin the law enforcement practices of the administrative bodies" , and in this context pays particular attention to "the relevance of the correct formulation of principles, because their clarity and consistency of the definition are reflected in the effectiveness of practical activities of administrative bodies" ${ }^{8}$. It is worth supporting the scholar's position that the principles of administrative procedural law are the basis for the proper law enforcement practices of the public administration bodies. The authors of the textbook "Administrative Law of Ukraine. The complete course" quite reasonably reckon that "as of today, when there is a legislative and regulatory framework for the implementation of administrative procedures, there are several drafts of omnibus acts dedicated solely to the normalization of these issues, there is every reason to speak about the possibility and expediency of formulating a system of principles of administrative procedures"'. Therefore, it can be said that today objectively 'the time is ripe' for the question of studying the principles of administrative and procedural law to aid the further development of this sub-branch of administrative law, normalization of relations between public administration bodies and individuals, and improvement of administrative procedural legislation. I.V. Kryvoruchko rightly states that "the effectiveness of the administrative procedure depends directly, among other things, on the completeness and quality of the legal confirmation of the principles that determine it. The identification and comprehension of the content of these principles require reference to a certain range of legal acts that regulate the

\footnotetext{
${ }^{5}$ Миколенко О.I. Місце адміністративного процедурного права в системі юридичних знань та системі права України : автореф. дис ... д-ра юрид. наук. 12.00.07 : Запоріжжя, 2011. C. 16.

${ }^{6}$ Ibid.

7 Лагода О.С. Адміністративна процедура: теорія і практика застосування : автореф. дис... канд. юрид. наук: 12.00.07. Ірпінь, 2007. С. 19.

${ }^{8}$ Ibid.

${ }^{9}$ Адміністративне право України. Повний курс : підручник / Галунько В., Діхтієвський П., Кузьменко О., Стеценко С. та ін. Херсон : ОЛДІ-ПЛЮС, 2018. С. 208.
} 
sphere of public administration activities ${ }^{10}$. In addition, I.V. Kryvoruchko, as a specialist in the field of public administration, states that the question of the principles of administrative procedure is "a phenomenon that is on the border of such two disciplines as public administration and law, primarily its administrative branch, which is conditioned by the notion of administrative procedure as a formalized order, regulated by the rules of administrative law and one of the procedural types of activity of public administration bodies in the exercise of the rights, freedoms, duties and interests of individuals and legal entities"11. In view of this position, it should be noted that the principles of administrative procedural law do have a "dual" legal nature, because, first, they determine the general direction of the exercise of legal powers by public administration bodies (in particular, we refer to the procedural aspect), and, second, they define the fundamental provisions of the relationship between public administration and private individuals. According to Yu.M. Frolov, "the initial provisions of administrative procedural activity are being confirmed in the principles of applying administrative procedures. Implementation of modern principles of administrative procedure into the law enforcement activities of public administration bodies is essential for the effective regulation of administrative procedural relations of the authorities with other entities of legal relations, since the principles are the necessary basis which allows protecting the rights and legitimate interests of any person in the relations with the state and helps limit manifestations of bureaucracy, abuse of power and corruption on the part of the public employees, improving the efficiency of these public authorities" S.V. Chyryk points out that "the definition and analysis of ways of formation and development of the principles of administrative procedure, their essence, system, legal regulation and directions of improvement of procedural legislation are becoming more and more relevant in connection with guaranteeing the constitutional rights of individuals and legal entities in this field, ensuring procedural safety of the state. These and other issues call for scholarly substantiation of the holistic concept of administrative procedure principles, examination of the nature, functions, main legal categories and classifications, review of the history of development and stages of formation of administrative procedure principles in Ukraine, summarizing the historical experience of their development in foreign countries, their possible use in our state, determining trends in the evolution of the procedural sphere, the

10 Криворучко І.В. Класифікація принципів адміністративної процедури та ії застосування наукою державного управління. Наук. вісн. Акад. муніцип. упр.: зб. наук. пр. Серія «Управління». 2016. Вип. 1. С. 71..

${ }^{11}$ Криворучко І.В. Визначення поняття принципів адміністративної процедури в науці державного управління. Вісник НАДУ при Президентові України. 2016. № 1. С. 23.

12 Фролов Ю. М. Класифікація принципів адміністративних процедур. Форум права. 2013. № 4. C. 423. URL: http://nbuv.gov.ua/UJRN/FP_index. 
adaptation of existing administrative procedural legislation to international law standards"13. A.M. Shkolyk completely legitimately notes that "the principles of administrative procedure should be used as guidelines in the practical activity by public administration bodies, and more specifically by particular civil servants and officials of local self-government (the last two terms accord with the current legislation of Ukraine). In particular, the importance of the principles increases in cases where normative legal acts do not regulate this activity of public administration in a sufficiently detailed manner and, accordingly, give these entities a sphere of administrative discretion limited by legal instructions. In such a situation, the very principles can and should become the benchmarks for the good (proper) fulfillment by the public administration bodies and specific public officials of their tasks and functions"14. So, the scholar appropriately underlined the "super-level" position of the principles of administrative procedural law in comparison with the rules of law. At the same time, T.O. Kolomoiets rightly emphasizes that "the principles of administrative procedure are not something amorphous, they are filled with real legal mechanisms and are in actual fact applied by participants of administrative procedural relations" ${ }^{\prime 15}$, with which one cannot but agree.

It should be mentioned that there is a trend not to use the concept of "principles of administrative procedural law" in the scholarly legal environment, but one can find such concepts as "principles of administrative procedure," "principles of administrative procedural regulation," "principles of administrative procedural activity," the development of which should be viewed as a prerequisite for the formation of a system of principles of administrative procedural law as a system of sub-branch principles of administrative law. Taking into consideration the definitions offered in the discipline-specific scholarly and educational sources, one can find positions according to which the principles of administrative procedures should be understood as "the key basic ideas which underlie procedural activities, are characterized by the universality and determine the direction of the actions of public administration entities"16; or "the main ideas (fundamentals), enshrined in the rules of law, that define the rules of engaging in an action,

\footnotetext{
13 Чирик С. В. Принципи адміністративної процедури. Адміністративна процедура: особливості формування украӥнської концепції : матеріли Круглого столу, м. Харків, 15 вересня 2017 р. - Харків : Національна академія правових наук України, Національний юридичний університет імені Ярослава Мудрого, 2017. С. 101.

${ }^{14}$ Школик А.М. Значення та перелік принципів адміністративної процедури. Вісник Запорізького національного університету. Юридичні науки. 2017. № 2. С. 93. URL: http://nbuv.gov.ua/UJRN/Vznu_Jur_2017_2_13.

${ }_{15}$ Коломоєць Т.О. Адміністративне право України. Академічний курс : підручник. Київ : Юрінком Інтер, 2011. С. 225.

${ }^{16}$ Адміністративне право України. Повний курс : підручник / Галунько В., Діхтієвський П., Кузьменко О., Стеценко С. та ін. Херсон : ОЛДІ-ПЛЮС, 2018. С. 208.
} 
decision-making, the conclusion of administrative contracts aimed at the exercise by individuals of their rights and obligations in the field of public administration and the satisfaction of public interest" ${ }^{\text {"17 }}$. N.L. Huberska believes that the principles of administrative procedures are "basic ideas, initial principles, intended to be applied in the implementation of a particular administrative procedure by an authorized state body, and aimed at protecting and realizing the rights, legitimate interests and responsibilities of individual and collective entities in the administrative relations" ${ }^{\prime 18}$. A.A. Pukhtetska notes that the principles of administrative procedure should be understood as "the basic requirements that should guide the parties in administrative proceedings, including the administrative body, when considering and resolving individual administrative cases"19, adding that "the principles of administrative procedure are key to a proper legal regulation of the procedure for resolving individual administrative cases and for the correct application of the relevant legal rules" ${ }^{\text {"20 }}$. A generalized analysis of all the above-mentioned provisions allows us to define the principles of administrative procedural law as universal, fundamental and conditioned by the social laws, moral principles and legal customs; the basic ideas and guiding provisions, enshrined in administrative procedural rules, which are the basis for the relations of public administration entities with private individuals and other entities while resolving individual administrative cases in the field of public administration.

\section{Attributes of the principles of administrative procedural law}

In order to explore the true potential and the real resource of the principles of administrative procedural law, it is necessary to draw up a general description of the characteristics that are inherent to them and allow them to be unified into a separate block of principles. Given the insufficient amount of research on the issues of administrative procedural law (in scholarly, publicistic, monographic works), one can say that unfortunately, the problem of identifying the attributes of administrative procedural law has not yet been conclusively resolved; the question of their essence still remains controversial and needs additional substantiation and concretization in the conditions of modern governmental and political transformations. So, we will try to offer an original list of attributes of the principles of administrative procedural law.

17 Адміністративна процедура : конспект лекцій / I. В. Бойко, О. Т. Зима, О. М. Соловйова ; за заг. ред. І. В. Бойко. Харків : Право, 2017. С. 20.

18 Губерська Н.Л. Основні принципи організації та реалізації адміністративних процедур. Публічне Право. 2015. № 1(17). С. 54.

19 Пухтецька А.А. Принципи адміністративного права: адміністративно-правові та євроінтеграційні аспекти оновлення змісту та практики застосування : монографія. Київ ; Харків : ПП Панов, 2016. С. 203.

${ }^{20}$ Ibid. C. 304. 
It is quite logical to begin the analysis of the attributes of the principles of administrative procedural law with such an attribute as the presence of $a$ specific sphere of regulatory influence, namely, administrative procedural activity. So, for example, I.V. Boiko, analyzing the formation of the institute of administrative procedure in modern legal science, notes that "the idea of human-centrism, which originated with the independence of the Ukrainian state and was enshrined in the Constitution of Ukraine, fully accepted by administrative scholars, played the role of a catalyst for the development of administrative law doctrine towards ensuring the rights of individuals who exercise them in relations with the public administration. It pushed administrative law away from the outdated paradigms in which a person was given the place of the object of managerial influence exercised by the state, and apparently formed an idea of administrative law as a branch of law, the main purpose of which is the realization and protection of human and citizen rights in the sphere of public administration" ${ }^{21}$. These very circumstances were the impetus also for the formation of such a sub-branch of administrative law as administrative procedural law, within the framework of which the concept of "administrative procedural activity" should be examined. In public administration, the procedure is central, because "the primary purpose of public administration entities is to resolve specific administrative cases by adopting administrative acts. The vast majority of such cases are positive in nature, aimed at the exercise of the rights of individuals and not related to the jurisdictional activities of public administration" 22 . T.O. Kolomoiets points out that administrative procedural activity is "the activity of administrative bodies not related to the administration of justice in administrative cases" and that "although it is related to certain actions that involve consistency and duration over time, but it is not related to justice," and therefore "should not be regarded as an analogue of administrative litigation," furthermore "this activity is not processual, though it is specific"23 Taking into account these theses, it should be noted that administrative procedural activity is public in nature, as it is manifested in the sphere of functioning of public administration bodies and is accompanied by the exercise of governmental authority powers; it is characterized by a sequence of administrative actions and decisions; it differs

${ }^{21}$ Бойко І.В. Становлення інституту адміністративної процедури в сучасній правовій науці. Публічне адміністрування в умовах змін та перетворень : проблеми організації та правового забезпечення: зб. наук. пр. за матеріалами III Міжнар. наук-практ. конф (м. Харків, 11-12 квіт 2019 р.). Харків : Право, 2019. С. 358.

22 Адміністративна процедура : конспект лекцій / I. В. Бойко, О. Т. Зима, О. М. Соловйова ; за заг. ред. І. В. Бойко. Харків : Право, 2017. С. 5.

${ }^{23}$ Коломоєць Т. О. Термінологія адміністративного процесу: проблеми визначеності суміжного термінологічного ряду. Наукові праиі Наиіонального університету "Одеська юридична академія". 2012. Т. 11. С. 339. URL: http://nbuv.gov.ua/UJRN/Nponyua_ 2012_11_36. 
in its personalized nature as it relates to the interests of individuals; it is nonconflicting in nature, since it is aimed at resolving positive cases that arise in the process of exercising governmental authority functions.

In addition, such a feature of the principles of administrative procedural law as universality and general validity is worth being singled out. The universality of the principles of law means that they "pervade all legal matter and they must be taken into account in any legal situation. The universality of the principles of law presupposes that they guide the whole mechanism of legal regulation of social relations" 24 .

Similarly, the principles of administrative procedural law proposed within the framework of the administrative legal science and enshrined in administrative legislation have a universal orientation, they must be such that they can be applied to any kind of administrative procedure. Alongside this, such an attribute reflects "the possibility of transferring the principles to any administrative procedural relationship, regardless of their subject, object or content, that is, the effect of the principles of administrative procedural law is non-personified and inexhaustible. The impersonality, that is, the absence of reference to a particular addressee, allows the principles to be applied not to one person but to many not listed by name. The inexhaustibility of the principle means the possibility of its repeated implementation. In other words, the principle establishes a rule (standard) for an indefinite (potentially infinite) number of cases of a certain kind and an unknown number of persons of a certain category." 25 Furthermore, one should support A.A. Pukhtetska in that "the basic principles of the administrative procedure have a constitutional basis. In particular, the provisions of the Constitution of Ukraine imply the principles: the supremacy of law, the reign of law, equality before the law and the guarantee of the protection of the law" 26 , which once again confirms the universality and general validity of the principles of administrative procedural law.

Taking into account the fact that the principles of law are "a product of the consciousness and will of people that contain certain orders, regulations, rules of conduct, that are implemented into life by the society and the state and that regulate as much as the law itself regulates" ${ }^{27}$, it is reasonable to propose to name the regulatory character as the next feature in the list of

24 Явич Л.С. Право развитого социалистического общества. Сущность и принципы. Москва : Юрид. лит., 1978. С. 11.

25 Погребняк С.П. Основоположні принципи права (змістовна характеристика): монографія. Харків: Право, 2008. С. 22.

${ }^{26}$ Пухтецька А.А. Принципи адміністративного права: адміністративно-правові та євроінтеграційні аспекти оновлення змісту та практики застосування : монографія. Київ ; Харків : ПП Панов [вид.], 2016. С. 304.

27 Міжнародно-правові аспекти Конституції України / [Ю. С. Шемшученко, Ф. Г. Бурчак, В. В. Цвєтков та ін.] ; під ред. В. М. Семенова, О. Я. Прагнюк. Ін-т держави і права ім. В. М. Корецького НАН України. Київ : Ін Юре, 1997. С. 12-14. 
attributes. Due to the high level of generalization of legal ideas, the principles determine the general foundations of both the whole sub-branch of administrative procedural law and its individual components (varieties of administrative procedures). Their purpose is to regulate the conduct of the subjects of administrative procedural law by setting certain frameworks for them, and, therefore, the principles are not only a means of reflecting ideas and views that are dominant in the state, they also include requirements for the parties in these legal relationships, being an important tool of regulating these relations. Of course, administrative procedural regulation is carried out on the basis of administrative procedural rules, but all rules of administrative legislation must be consistent with and based on the principles of administrative procedural law. O.V. Starchuk believes that "the regulatory character is an auxiliary attribute of the principles, because social relations are regulated by the rules of law. And so all the rules of law have a regulatory character, and the principles determine the norm itself, because they underlie it. However, the regulation of social relations by means of principles is carried out in individual cases, in particular, in the absence of such a norm (analogy of statute), the general principles of law (analogy of law) are applied"28. At the same time, the regulatory features of the principles cannot be equated with the regulatory characteristics of the rules of law, since the principles are more abstract. In this case, the regulation of administrative procedural relations is carried out from "higher" positions, because, using only principles, it is impossible to regulate specific legal relations in all cases.

Attributes of the principles of administrative procedural law include social conditionality. This attribute implies that, as a rule, the ideas that are in congruence with the socio-economic conditions of the social development, as well as political, ideological and other processes taking place in the state, are transformed into principles. This feature reflects the content of the law with its social foundations - those patterns of social life on which a specific legal framework is built. After all, the principles in their original form (up to the moment of well-formedness) are worldview ideas, a consequence of views, beliefs, conceptions, ideals, life or scholarly doctrinal directions (which can be reflected, for example, in the "duty of good faith," the "principle of honesty," the "principle of politeness," etc.) dominant in the society. The subjects of formation of such ideas are individuals, their association, the society as a whole. For example, such a criterion as good faith "requires the subject of authority to act in good faith, that is, with a sincere intention to exercise its authority and commitment to the purpose and task of the law, without the selfish desire to achieve personal gain, privilege

${ }^{28}$ Старчук О.В. Щодо поняття принципів права. Часопис Київського університету права. 2012. № 2. С. 41. 
or advantage through committing actions or making decisions. Good faith decision-making, action or inaction do not preclude the possibility of deviation from the law, but exclude the intent for such a violation. Good faith can be understood as an aspect of the requirement that a person should not abuse his or her rights and perform the duties required by law. At the same time, this requirement is aimed not only at the protection of the public interest, but also at the protection of the rights and legitimate interests of other persons, given the possibility that the parties in the proceedings might have different status (and interests)." 29 Theoretical generalizations, legal theories, through objectification in the rules of law or doctrinal studies, become the principles of administrative procedural law. The content of the principles is determined by objective social laws.

Another attribute of the principles of administrative procedural law is their normative regulatedness. O.H. Kotenov points out that "the principles of law are of the same nature as the law of which they are a part. Law, in turn, materializes in relevant sources of law. Therefore, it is logical to conclude that the principle of law must be enshrined in some way in normative acts or other sources of law. However, it should be emphasized that it is appropriate or even compulsory to enshrine the principles of law in legislation when it is necessary to put into effect certain principles" ${ }^{30}$. The content of the concept of "normative regulatedness" includes the confirmation or reflection of the principle in the rules of law. Until such a confirmation, a fundamental idea, which has the status of an "applicant" for the role of a principle, and is not yet enshrined in law, cannot be considered a principle of law, it remains only a theoretical, scholarly idea that belongs to the system of the research area of legal science. It is possible to say that no ideas per se can regulate legal relations, until they are enshrined in legal norms and acquire the governmental authority character as well as attributes of normative regulatedness. At the same time, the confirmation of the principles in the rules of law should ensure the continued adherence to them under the threat of negative consequences for the offenders or under the threat of the cancellation of decisions taken in cases with such violation $^{31}$. O.M. Soloviova and V.A. Somina state that "the relationship of administrative bodies with individuals (legal entities and natural persons) should be clearly regulated by law and based on fundamental principles of public administration, which will ensure the effective implementation of the

29 Пухтецька А.А. Принципи адміністративного права: адміністративно-правові та євроінтеграційні аспекти оновлення змісту та практики застосування : монографія. Київ ; Харків : ПП Панов [вид.], 2016. С. 319.

${ }^{30}$ Котеньов О.Г. Принципи права природокористування : дис. ... канд. юрид. наук : 12.00.06. Харків, 2017. С. 42.

31 Козюбра Н. И. Социалистическое право и общественное сознание. Киев: Наук. думка, 1979. С. 189. 
basic tasks and functions of the state on the one hand, and, observance of the rights and legal interests of natural persons and legal entities in all spheres of state activity on the other hand"32. That is why this attribute reflects the guarantee of the strict observance of the basic provisions expressed in the principles of administrative procedural law by all law enforcement agencies.

Given that the principles of administrative procedural law constitute a logical sequence rather than operate in a chaotic fashion, it is necessary to pay attention to such an attribute as their systematicity. The principles are an interconnected system of legal rules, which is the basis of the whole scope of administrative legislation including its procedural sub-branch. The importance of each principle is determined not only by its own content, but also by the functioning of the whole system of principles, which implies their interconnection, interdependence, as well as the consistency of their content and forms of implementation. This interconnection ensures the unity of all spheres and areas of administrative procedural law. The principles must not only be mutually consistent but also comply with other elements of legal regulation. An important issue to be considered when forming a holistic view of the system of principles is the importance of each. Summarizing the above, one can argue that within the entire system each of the principles has its own content which should not duplicate the other principles. At the same time, the principles precondition each other and very often serve as guarantees of the realization of other principles. They necessarily complement rather than contradict each other, and determine the structure of administrative procedural law as a whole. However, the individual principles are in equilibrium or in competition.

Among the attributes of the principles of administrative procedural law one should distinguish such a feature as fundamentality. Principles are most often defined as the most general, principal and fundamental legal provisions and ideas distinguished by their paramount character with respect to other rules of administrative procedural activity, which, in turn, should be derived from the principles, be based on them, specify the effect of one or another principle, but in no way contradict them. Thus, due to its generality, each principle sufficiently "brightly" characterizes the essence of administrative procedural law. The ideas that underpin the system of principles of administrative procedural law are a compromise that arises on the basis of the aggregation of several, sometimes competing, ideas of a smaller scale. As a result of such a generalizing association, a general idea emerges that is capable of influencing a wider range of administrative procedural relations. The fundamentality of the principles determines their content, nature and

32 Соловйова О.М., Сьоміна В.А. Щодо принципів адміністративної процедури. Адміністративна процедура: особливості формування украӥнської концепиї : матеріли Круглого столу, м. Харків, 15 вересня 2017 р. - Харків : Національна академія правових наук України, Національний юридичний університет імені Ярослава Мудрого, 2017. С. 92. 
legitimacy: the principles may be the basis for changing individual administrative procedural rules. In addition, as an exception to the general rules of the functioning of legal norms, the principles have a retroactive effect, enabling them to extend their effect to any rule that had been confirmed earlier than the principle itself, including its cancellation and nonrecognition of its consequences.

It is worth singling out such an attribute of the principles of administrative procedural law as their stability. While the rules of administrative procedural law are sufficiently variable and are adopted and modified for the proper regulation of administrative procedural relations, the principles of administrative procedural law are long-lasting, which testifies to their stability. So, for example, R. David and K. Geoffre-Spinozi state that "the rules of law may change with a stroke of the pen of the legislator. However, they have many such elements that cannot be freely altered because they are closely linked to our civilization and our way of thinking. The legislature cannot influence these elements" ${ }^{\prime 3}$. The authors are apparently referring to the principles of law. It should be emphasized that the higher the position of a certain principle in a hierarchical system of principles is, the less variable it is. Such principles as the principle of justice, equality, freedom, humanism, which are universal principles of law, have the most sustainable character, thus ensuring the stability of legal regulation. The principles of law "change not so much in terms of their own formula, but rather in terms of the social content that is poured into this formula" ${ }^{34}$. At the same time, such a stable nature of the principles of law does not prevent them from simultaneously ensuring the dynamism of legal regulation. According to M.I. Koziubra, legal regulation is carried out "not only by the rules of law, which stipulate what specific actions should be taken and from which one should abstain, but also by the principles of law (at all their levels - general, branch, inter-branch, principles of the institutes of law). Unlike the rules of law, the principles of law do not "rigidly" establish the content of behavior, they are able to respond "more quickly" to changes in public life. The general principles of law (justice, liberty, equality, etc.) are endowed with a particularly large "power reserve" in this respect" 35 .

A separate attribute of the principles of administrative procedural law to be distinguished is their progressiveness, since they contribute to the development of the sub-branch and are aimed at improving its individual constituent elements. Given the general lexical meaning of the word "progressive" as: "1) promoting progress; politically, socially, economically

33 Давид Р., Жоффре-Спинози К. Основные правовые системы современности ; пер. с фр. В. А. Туманова. Москва.: Междунар. отношения, 1999. С. 19-20.

34 Явич Л. С. Проблемы правового регулирования советских общественных отношений. Москва: Юрид. лит., 1961. С. 153.

35 Козюбра Н.И. Социалистическое право и общественное сознание. Киев.: Наук. думка, 1979. С. 187-188. 
advanced; the one which leads to improvement, enhancement of something thanks to their ideas, moods, views; the one that strives for progress by sharing ideas, moods, views, and fights for progress; 2) the one that gradually grows, enlarges, increases proportionally" ${ }^{\prime 36}$, it can be argued that it fully reflects the role and influence of the principles on the formation and improvement of the sub-branch of administrative procedural law. P.M. Rabinovych, defining the content of the universal human principles, states that these are "legal foundations, ideals that determine a certain level of world civilization development, embody the progressive achievements of the legal history of mankind and are widely recognized in international regulations" ${ }^{37}$. That is, taking into account the progressive achievements of the legal history of mankind in order to effectively regulate social relations is characteristic of the principles. Thus, according to the authors of the textbook "Administrative Law of Ukraine. A Complete Course", the principles of administrative law are characterized by progressiveness, and attest to the fundamental foundations of the conduct of the subjects of administrative law, ideal under the modern conditions, that are actually attainable ${ }^{38}$. And taking into consideration the extension of the principles of administrative law to all its components (including the sub-branch of administrative procedural law), it is possible to assume by analogy that the principles of the latter are also characterized by progressiveness.

An unmistakable attribute of the principles of administrative procedural law is their inviolability. Ignoring the principles or their violation by the legislator, public administration or other entities of administrative procedural law may undermine the stability of the legal system, adversely affect the state of legal consciousness or violate the legal order. So, "an administrative authority, when resolving an administrative case, is obliged to use its legal power for the purpose for which such power is conferred. The purpose of the legal power is defined by the law or follows from its purposes. The criterion of the use of the legal powers for the proper purpose is extremely important for the control over the legality of the activities of administrative bodies, first of all, in administrative litigation and the adoption of administrative acts. Decision making, taking action using authority for the purpose with which that authority is granted constitute the criterion that can be formulated as a principle of using authority for a proper purpose. ... The use of legal powers with improper purpose is an intrinsic abuse of them: namely, using them

\footnotetext{
${ }^{36}$ Словник української мови : у 11 т. / гол. ред. кол. І. Білодід. Київ : „Наукова думка”, 1970-1980. Том 8, 1977. C. 159. URL: http://sum.in.ua/s/proghresyvnyj.

37 Рабінович П.М. Принципи права // Юридична енциклопедія: В 6 т. / [за ред.

Ю. С. Шемшученко (голова ред. кол.) та ін.]. К.: Вид-во «Українська енциклопедія» імені М. П. Бажана, 1998-2004. Т. 5. 2003. С. 128.

${ }_{38}$ Адміністративне право України. Повний курс : підручник / Галунько В., Діхтісвський П., Кузьменко О., Стеценко С. та ін. Херсон : ОЛДІ-ПЛЮС, 2018. С. 40.
} 
dishonestly, with wrongful intentions, with ill will, with a distorted interpretation of the purpose with which the legal power was given, with a personal interest in taking a decision or taking an action" 39 . That is why a violation of any principle must necessarily entail the responsibility of the law enforcement entities and / or the annulment or review of the decision in the case of such violation. The principles have other important features and characteristics, but the ones listed above are basic for the characterization of the principles of administrative procedural law.

\section{CONCLUSIONS}

Thus, it should be noted that at present, the concept of principles of administrative procedural law has not yet been formed within the framework of the administrative legal science, which gives rise to discussions concerning their inventory and content, as well as their role in the relevant sub-branch of administrative law. This necessitates the exploration of this basic concept in the field of this sub-branch of administrative law. Among the attributes inherent in the principles of administrative procedural law the following ones should be named: the presence of a specific sphere of regulatory influence - administrative procedural activities, universality and general validity, regulatory character, social conditionality, normative regulatedness, systematicity, fundamentality, stability, progressiveness, and inviolability. The principles reflect the worldview ideas concerning a proper model of the relationship between public administration entities and individuals; they express the essence of the rules of conduct of such entities; they act systematically as a set of basic and general rules; their effect extends to all kinds of administrative procedures; they cause improvements in the sub-branch, and their violation entails the cancellation or revision of decisions in the case or the use of other means of liability.

\section{SUMMARY}

In the paper, on the basis of the provisions of domestic doctrinal administrative law, characteristic features of the principles of administrative procedural law are analyzed. The relation between the principles of administrative law (as a general, large-scale concept) and the principles of administrative procedural law (as their integral part) is traced. The essence of the concept of "principles of administrative procedural law" has been clarified, taking into account the provisions and trends of the domestic administrative law science. An original list of attributes of the principles of administrative procedural law is offered and their content is elucidated.

39 Пухтецька А.А. Принципи адміністративного права: адміністративно-правові та євроінтеграційні аспекти оновлення змісту та практики застосування : монографія. Київ ; Харків : ПП Панов [вид.], 2016. С. 314.

212 


\section{REFERENCES}

1. Адміністративне право : підручник / [Ю.П. Битяк, В.М. Гаращук, В.В. Богуцький та ін.] ; за заг. ред. Ю. П. Битяка, В.М. Гаращука, В.В. Зуй. Харків : Право, 2010. 624 с.

2. Колпаков В.К., Кузьменко О.В. Адміністративне право України : підруч. Київ : Юрінком Інтер, 2003. 544 с.

3. Пухтецька А.А. Принципи адміністративного права: адміністративно-правові та євроінтеграційні аспекти оновлення змісту та практики застосування : монографія. Київ ; Харків : ПП Панов [вид.], 2016. 434 с.

4. Коломоєць Т.О., Баранчик П.О. Принципи адміністративного права : монографія. Запоріжжя : Поліграфичний центр «Сору Art», 2012. $203 \mathrm{c}$.

5. Кравцов А.С. Пріоритет прав і свобод людини та громадянина як принцип адміністративного права України: автореф. дис. ... канд. юрид. наук : 12.00.07. Київ, 2011. 19 с.

6. Мельник Р.С. Інститут принципів адміністративного права у системі Загального адміністративного права України. Публічне право. 2012. № 3 (7). С. 51-60.

7. Миколенко О.I. Місце адміністративного процедурного права в системі юридичних знань та системі права України : автореф. дис ... д-ра юрид. наук. 12.00 .07 : Запоріжжя, 2011.40 с.

8. Лагода О.С. Адміністративна процедура: теорія і практика застосування : автореф. дис... канд. юрид. наук: 12.00.07. Ірпінь, 2007. 21 с.

9. Адміністративне право України. Повний курс : підручник / Галунько В., Діхтієвський П., Кузьменко О., Стеценко С. та ін. Херсон : ОЛДІ-ПЛЮС, 2018. 446 с.

10. Криворучко I.В. Класифікація принципів адміністративної процедури та іiі застосування наукою державного управління. Наук. вісн. Акад. муніциип. упр.: зб. наук. пр. Серія «Управління». 2016. Вип. 1. C. 64-74.

11. Криворучко I.В. Визначення поняття принципів адміністративної процедури в науці державного управління. Вісник НАДУ при Президентові України. 2016. № 1. С. 20-25.

12. Фролов Ю. М. Класифікація принципів адміністративних процедур. Форум права. 2013. № 4. С. 423-429. URL: http://nbuv.gov.ua/ UJRN/FP_index.

13. Чирик С. В. Принципи адміністративної процедури. Адміністративна процедура: особливості формування украӥнської концепиії : матеріли Круглого столу, м. Харків, 15 вересня 2017 р. - Харків : Національна академія правових наук України, Національний юридичний університет імені Ярослава Мудрого, 2017. С. 101-105.

14. Школик А.М. Значення та перелік принципів адміністративної процедури. Вісник Запорізького наиіонального університету. Юридичні 
науки. 2017. № 2. С. 91-98. URL: http://nbuv.gov.ua/UJRN/Vznu_ Jur_2017_2_13.

15. Коломоєць Т.О. Адміністративне право України. Академічний курс : підручник. Київ : Юрінком Інтер, 2011. 576 с.

16. Адміністративна процедура : конспект лекцій / І.В. Бойко, О.Т. Зима, О.М. Соловйова ; за заг. ред. І.В. Бойко. Харків : Право, 2017. $132 \mathrm{c}$.

17. Губерська Н.Л. Основні принципи організації та реалізації адміністративних процедур. Публічне Право. 2015. № 1(17). С. 48-56.

18. Бойко І.В. Становлення інституту адміністративної процедури в сучасній правовій науці. Публічне адміністрування в умовах змін та перетворень : проблеми організачії та правового забезпечення: зб. наук. пр. за матеріалами III Міжнар. наук-практ. конф (м. Харків, 11-12 квіт 2019 р.). Харків : Право, 2019. С. 358-361.

19. Коломоєць Т.О. Термінологія адміністративного процесу: проблеми визначеності суміжного термінологічного ряду. Наукові прачі Національного університету «Одеська юридична академія». 2012. Т. 11. C. 335-343. URL: http://nbuv.gov.ua/UJRN/Nponyua_2012_11_36.

20. Явич Л.С. Право развитого социалистического общества. Сущность и принципы. Москва : Юрид. лит., 1978. 224 с.

21. Погребняк С.П. Основоположні принципи права (змістовна характеристика): монографія. Харків: Право, 2008. 240 с.

22. Міжнародно-правові аспекти Конституції України / [Ю.С. Шемшученко, Ф. Г. Бурчак, В. В. Цвєтков та ін.] ; під ред. В.М. Семенова, О.Я. Прагнюк. Ін-т держави і права ім. В. М. Корецького НАН України. Київ : Ін Юре, 1997. С. 12-14.

23. Старчук О.В. Щодо поняття принципів права. Часопис Київського університету права. 2012. № 2. С. 40-43.

24. Котеньов О.Г. Принципи права природокористування : дис. ... канд. юрид. наук : 12.00.06. Харків, 2017. 228 с.

25. Козюбра Н.И. Социалистическое право и общественное сознание. Киев: Наук. думка, 1979. 208 с.

26. Соловйова О.М., Сьоміна В.А. Щодо принципів адміністративної процедури. Адміністративна прочедура: особливості формування української концепції : матеріли Круглого столу, м. Харків, 15 вересня 2017 р. - Харків : Національна академія правових наук України, Національний юридичний університет імені Ярослава Мудрого, 2017. C. $92-101$.

27. Давид Р., Жоффре-Спинози К. Основные правовые системы современности ; пер. с фр. В. А. Туманова. Москва.: Междунар. отношения, $1999.400 \mathrm{c}$.

28. Явич Л.С. Проблемы правового регулирования советских общественных отношений. Москва: Юрид. лит., 1961. 172 с. 
29. Словник української мови : у 11 т. / гол. ред. кол. І. Білодід. Київ : «Наукова думка», 1970-1980. Том 8, 1977. С. 159. URL: http://sum.in.ua/s/proghresyvnyj.

30. Рабінович П.М. Принципи права // Юридична енциклопедія: В 6 т. / [за ред. Ю. С. Шемшученко (голова ред. кол.) та ін.]. К.: Вид-во «Українська енциклопедія» імені М. П. Бажана, 1998-2004. Т. 5. 2003. C. 128.

Information about the authors: Sharaia A. A., Candidate of Juridical Sciences, Zaporizhzhia National University 66, Zhukovskoho str., Zaporizhzhia, 69600, Ukraine

Pokataiev P. S., Doctor of Law, Doctor of Sciences of the State Administration, Professor, First Vice-Rector, Classic Private University 70b, Zhukovskoho str., Zaporizhia, 69002, Ukraine 